\title{
Analysis of Patient Factors Affecting In Vitro Characteristics of Subacromial Bursal Connective Tissue Progenitor Cells during Rotator Cuff Repair
}

\author{
Daichi Morikawa ${ }^{1,2, *}$, Benjamin C. Hawthorne ${ }^{1}$, Mary Beth R. McCarthy ${ }^{1}$, Nicholas Bellas ${ }^{1}$, \\ Jeremiah D. Johnson ${ }^{1}$, Maxwell T. Trudeau ${ }^{1}{ }^{(\mathbb{D}}$, Kyle V. Murphy ${ }^{1}$, Michael R. Mancini ${ }^{1}$, Matthew R. LeVasseur ${ }^{1}$, \\ Mark P. Cote ${ }^{1}$ and Augustus D. Mazzocca ${ }^{1, *}$
}

Citation: Morikawa, D.; Hawthorne, B.C.; McCarthy, M.B.R.; Bellas, N.; Johnson, J.D.; Trudeau, M.T.; Murphy, K.V.; Mancini, M.R.; LeVasseur, M.R.; Cote, M.P.; et al. Analysis of Patient Factors Affecting In Vitro

Characteristics of Subacromial Bursal Connective Tissue Progenitor Cells during Rotator Cuff Repair. J. Clin. Med. 2021, 10, 4006. https://doi.org/ $10.3390 / \mathrm{jcm} 10174006$

Academic Editor: Oleg Dolkart

Received: 9 August 2021

Accepted: 2 September 2021

Published: 4 September 2021

Publisher's Note: MDPI stays neutral with regard to jurisdictional claims in published maps and institutional affiliations.

Copyright: (c) 2021 by the authors. Licensee MDPI, Basel, Switzerland. This article is an open access article distributed under the terms and conditions of the Creative Commons Attribution (CC BY) license (https:// creativecommons.org/licenses/by/ $4.0 /)$.
1 Department of Orthopaedic Surgery, University of Connecticut, Farmington, CT 06032, USA; bhawthorne@uchc.edu (B.C.H.); mccarthy@uchc.edu (M.B.R.M.); nbellas@uchc.edu (N.B.); jejohnson@uchc.edu (J.D.J.); trudeau@uchc.edu (M.T.T.); kymurphy@uchc.edu (K.V.M.); mimancini@uchc.edu (M.R.M.); mlevasseur@uchc.edu (M.R.L.); mcote@uchc.edu (M.P.C.)

2 Department of Orthopaedic Surgery, Juntendo University Urayasu Hospital, Urayasu 279-0021, Japan

* Correspondence: dmorikaw@juntendo.ac.jp (D.M.); mazzocca@uchc.edu (A.D.M.)

\begin{abstract}
Unsatisfactory failure rates following rotator cuff $(\mathrm{RC})$ repair have led orthopaedic surgeons to explore biological augmentation of the healing enthesis. The subacromial bursa (SB) contains abundant connective tissue progenitor cells (CTPs) that may aid in this process. The purpose of the study was to investigate the influence of patient demographics and tear characteristics on the number of colony-forming units (CFUs) and nucleated cell count (NCC) of SB-derived CTPs. In this study, we harvested SB tissue over the supraspinatus tendon and muscle in 19 patients during arthroscopic RC repair. NCC of each sample was analyzed on the day of the procedure. After 14 days, CFUs were evaluated under a microscope. Spearman's rank correlation coefficient was then used to determine the relationship between CFUs or NCC and patient demographics or tear characteristics. The study found no significant correlation between patient demographics and the number of CFUs or NCC of CTPs derived from the SB $(p>0.05)$. The study did significantly observe that increased tear size was negatively correlated with the number of CFUs $(p<0.05)$. These results indicated that increased tear size, but not patient demographics, may influence the viability of CTPs and should be considered when augmenting RCrepairs with SB.
\end{abstract}

Keywords: subacromial bursa; rotator cuff; mesenchymal stem cells; connective tissue progenitors; shoulder

\section{Introduction}

Rotator cuff (RC) pathology is one of the most common etiologies of shoulder dysfunction with more than 4.5 million physician visits annually [1]. The leading treatment choice following failure of conservative measures remains surgical repair of the torn tendon back to its humeral attachment. Day et al. reported that from 2007 to 2015, there was a $188 \%$ increase in total RC repairs in the United States [2]. Despite advancements in surgical material and techniques, retear rates following RC repairs approximate 10 to $94 \%$ depending on the patient population [3-5]. A major issue following repair of the tendon to bone interface is failed enthesis regeneration; instead of the enthesis regenerating to its native form, healing results in a mechanically inferior fibrous scar [6-8].

Several approaches for augmenting the healing tendon have been proposed and developed, including pharmacological, biological scaffolds and stem/progenitor cell transplantation [9-11]. "Stem cell" transplantation for tendon repair has been explored from many sources, including embryonic stem cells (ESCs), induced pluripotent stem cells (iPSCs), and adult stem cells such as mesenchymal stem cells (MSCs) and adipose-derived 
stem cells $[12,13]$. Currently, in the United States, the FDA does not permit ex vivo culture expansion of cells as Regulation 21 CFR 1271 requires products to be homologous, minimally manipulated, and lack systemic effects $[14,15]$. Thus, the majority of stem cell research has searched for local populations of MSCs that that can be utilized intraoperatively in an efficient manner for a low cost $[11,14,16]$.

Previous literature has demonstrated that the subacromial bursa (SB) harbors a high concentration of cells that meet the International Society for Cellular Therapy (ISCT) criteria for MSCs [17-21]. When freshly harvested from patients, cells with characteristics of MSCs are more accurately described as connective tissue progenitors (CTPs) $[11,13,22,23]$. The bursal CTPs have been shown to have high proliferation/differentiation potential, as well as superior engraftment to host tendon in animal models [19,24-27]. Due to the ease of accessibility and inexpensive nature of harvesting the SB intraoperatively, surgical techniques have been developed to efficiently augment RC repairs with these CTPs [28-30]. Additionally, this process does not fall under the complex FDA regulations applied to that other "stem cell" therapies such as ESCs and iPSCs [14,31].

In order to determine which patients may be good candidates for biological augmentation during RCrepairs, it is important to understand how patient demographics alter characteristics of CTPs, as this may affect healing. Patients who are old, obese, diabetic, and smoke have previously been reported to have higher rates of RC repair failures compared to healthy patients [32-35]. Muench et al. was the first to demonstrate that SB CTPs demonstrated high proliferation potential regardless of patient demographics and RC tear characteristics [36]. The study was limited as it used nucleated cell count (NCC) as a proxy for cell proliferation, which is less specific for cellular activity of CTPs compared to colony-forming units (CFUs) $[13,22,37]$.

The purpose of this study was to further investigate the influence of patient demographics and tear size on the number of CFUs and NCC of SB-derived CTPs. The authors hypothesized that patient demographics and tear size would not be correlated to proliferative characteristics of SB CTPs.

\section{Materials and Methods}

\subsection{Patient Selection}

Patients were selected for this study from December 2016 to May 2018. These individuals had to be undergoing arthroscopic RC repair to be considered for enrollment. Institutional review board approval was acquired before initiation of the study (IRB no. IE-07-224-2). Inclusion criteria for patients selected for the study included an age $>18$ years and clinical indication for arthroscopic RC repair following the failure of alternative conservative therapy. Exclusion criteria included patients with a history of systemic infectious disease (sexually transmitted infections, Hepatitis infection, etc.) and patients who were pregnant, imprisoned, or deemed to be another form of a vulnerable population. Prior surgery to the affected shoulder was not cause for exclusion from the study. For every participant, basic demographic information (age, sex, height, weight, BMI), pertinent medical and surgical history, whether the patients smoked (never, former, current), and the duration they smoked (months) was collected. Smoking information was then used to determine a Brinkman index score based on cigarettes per day multiplied by years smoked to quantify the amount someone has smoked. The presence of diabetes mellitus, thyroid disease, and hypertension were also collected.

\subsection{Surgical Removal of Subacromial Bursal Tissue}

Harvest of SB was performed using techniques feasible in the setting of arthroscopic $\mathrm{RC}$ repair [25]. Bursal tissue samples were obtained using an arthroscopic grasper device in two locations in each patient for comparison, above the supraspinatus tendon and above the supraspinatus muscle. The samples were placed into sterile specimen cups filled with sterile normal saline. After collection, samples were immediately transported from the operating room to a laminar flow hood for processing. 


\subsection{Subacromial Tissue Processing}

For each sample, $200 \mathrm{mg}$ was carefully weighed for plating. As previously described, the sample was then digested in $2 \mathrm{mg} / \mathrm{mL}$ Collagenase P (Sigma-Aldrich, St. Louis, MO, USA) in Dulbecco's modified Eagle's medium (DMEM) $(1 \times$ Thermo Fisher Scientific, Waltham, MA, USA) at $37^{\circ} \mathrm{C}$ for $2 \mathrm{~h}[24,37]$. Following digestion, the cells were filtered through a 70-mm cell strainer (Fisher Scientific, Pittsburgh, PA, USA), the remnant was disposed of and the cells were centrifuged at $800 \times g$ for $5 \mathrm{~min}$ to obtain a cell pellet [21].

\subsection{Nucleated Cell Count}

After digestion, the cellular concentrations (cells $/ \mathrm{mL}$ ) were counted using a Z1 Coulter Particle Counter (Beckman Coulter Life Sciences, Indianapolis, IN, USA), calibrated to detect particles $>8 \mathrm{~mm}$, using a transparent cuvette containing $100 \mathrm{~mL}$ of cellular solution and $9.9 \mathrm{~mL}$ of $0.9 \% \mathrm{NaCl}$ solution for a total volume of $10 \mathrm{~mL}$. The number of nucleated cells was then calculated, using this cellular concentration, by multiplying by the volume of DMEM $(10 \mathrm{~mL})$. The cell mass density (cells $/ \mathrm{mg}$ ) was then calculated by normalizing with respect to the total mass of the harvested tissue.

\subsection{Colony-Forming Units}

After NCC, the cells were plated in complete culture medium containing DMEM, $10 \%$ fetal bovine serum (FBS) (Thermo Fisher Scientific), and $0.1 \%$ penicillin/streptomycin (Thermo Fisher Scientific) on Corning Primaria 100-mm dishes (Thermo Fisher Scientific) at a density of $10^{3}$ and $10^{4}$ for each bursa sample and were grown at $37^{\circ} \mathrm{C}$ in a $\mathrm{CO}_{2}$ incubator at $5 \%$ humidified $\mathrm{CO}_{2}[19,21]$. Complete DMEM medium was changed every 3 to 4 days. After 14 days in culture, dishes of each density were stained with $0.5 \%$ crystal violet solution for $10 \mathrm{~min}$. The cells were then washed twice with distilled water, and the number of colonies per dish was counted. Colonies measuring $<2 \mathrm{~mm}$ in diameter or faintly stained colonies were not included $[19,24,37]$.

\subsection{Radiographic Analysis}

All patients received magnetic resonance imaging (MRI) of the involved shoulder prior to surgery. MRI was utilized to determine tear size for each patient in the anteroposterior (AP) view. All MRIs were evaluated by two independent sports medicine trained orthopaedic surgeons.

\subsection{Statistical Analyses}

Continuous data were summarized using mean and standard deviation (SD), as well as median and interquartile ranges (IQR). Categorical variables were presented as frequencies and percentages. Spearman's rank correlation coefficient was utilized to assess statistical correlations between patient demographics and the number of CFUs and NCC of colonies by SB CTPs. These analyses were completed for both bursa over the RC tendon and bursa over the RC muscle. All $p$ values of $<0.05$ were considered statistically significant. Analyses were performed using Stata 17 (StataCorp LLC, College Station, TX, USA).

\section{Results}

\subsection{Subjects}

Nineteen patients underwent arthroscopic RC repair, performed by a single surgeon (ADM) from December 2016 to May 2018. The mean age of patients was $57.2 \pm 4.5$ years (median 57 years; IQR 54-60 years) and the majority of patients were female ( $n=10$; $52.6 \%$ ). The mean weight was $92.5 \pm 16.4 \mathrm{~kg}$ (median 88.5; IQR 82.6-102.9), the mean height was $169.5 \pm 9.9 \mathrm{~cm}$ (median 167.6; IQR 161.3-176.5), and the mean BMI was $32.5 \pm 5.5 \mathrm{~kg} / \mathrm{m}^{2}$ (median 32.4; IQR 29.2-34.4). The mean tear size was $18.6 \pm 9.3 \mathrm{~mm}$ (median 13.5; IQR 11.0-27.0). The majority of patients in the series $(84.2 \%)$ had a history of smoking (never: $n=6,31.6 \%$; current: $n=10,52.6 \%$; former: $n=3,15.8 \%$ ), resulting in a mean Brinkman Index of $300.6 \pm 386.8$ (median 50.0; IQR 0-573.3). Lastly, regarding 
chronic comorbidities, no patients in the series had rheumatoid arthritis, $21.1 \%$ of the cohort had diabetes mellitus, $15.8 \%$ had thyroid disease, and $66.7 \%$ had hypertension.

\subsection{Correlation between Number of CFUs and Patient Demographics}

There were no statistically significant correlations between number of CFUs from SB CTPs over RC tendon or muscle and the following patient demographics: age, sex, height, weight, BMI, smoking, Brinkman Index, diabetes mellitus, thyroid disease, and hypertension. Further details can be observed in Table 1.

Table 1. Spearman's rank correlation coefficient analysis of the number of Colony-Forming Units (CFUs) by cells from $\mathrm{SB}$ over the RC tendon and muscle. Correlation analysis between the number of CFUs and patient demographics was completed. While tear size was negatively correlated to the number of CFUs from both the cells from the SB over the RC tendon, there was no statistical correlation with other demographics. $\left({ }^{*}=\right.$ significance $\left.p<0.05\right)$.

\begin{tabular}{|c|c|c|c|c|c|c|c|c|}
\hline & \multicolumn{8}{|c|}{ Number of Colony Forming Units } \\
\hline & \multicolumn{4}{|c|}{ Bursa over Rotator Cuff Tendon } & \multicolumn{4}{|c|}{ Bursa over Rotator Cuff Muscle } \\
\hline & \multicolumn{2}{|c|}{$10^{3}$ Cells/Well } & \multicolumn{2}{|c|}{$10^{4}$ Cells/Well } & \multicolumn{2}{|c|}{$10^{3}$ Cells/Well } & \multicolumn{2}{|c|}{$10^{4}$ Cells/Well } \\
\hline & rho & $p$-Value & rho & $p$-Value & rho & $p$-Value & rho & $p$-Value \\
\hline Age & -0.179 & 0.522 & -0.319 & 0.246 & -0.036 & 0.899 & -0.013 & 0.965 \\
\hline Sex (Female) & 0.000 & 1.000 & -0.062 & 0.827 & -0.031 & 0.913 & 0.186 & 0.508 \\
\hline Height $(\mathrm{cm})$ & 0.097 & 0.732 & 0.138 & 0.624 & 0.116 & 0.680 & -0.091 & 0.746 \\
\hline Weight (kg) & -0.000 & 1.000 & -0.173 & 0.537 & 0.136 & 0.629 & -0.127 & 0.652 \\
\hline $\operatorname{BMI}\left(\mathrm{kg} / \mathrm{m}^{2}\right)$ & -0.189 & 0.499 & -0.368 & 0.177 & -0.129 & 0.648 & -0.161 & 0.567 \\
\hline Tear size $(\mathrm{mm})$ & -0.567 & $0.028 *$ & -0.645 & $0.009 *$ & -0.429 & 0.111 & -0.434 & 0.106 \\
\hline Smoking (Non, Former, Current) & -0.147 & 0.602 & -0.137 & 0.627 & 0.221 & 0.429 & -0.018 & 0.950 \\
\hline Brinkman Index (Ciggarettes $/ \mathrm{d} \times \mathrm{y}$ ) & 0.113 & 0.690 & 0.105 & 0.709 & 0.270 & 0.331 & 0.094 & 0.739 \\
\hline Diabetes mellitus (Yes) & -0.232 & 0.407 & -0.077 & 0.785 & -0.424 & 0.115 & 0.039 & 0.891 \\
\hline Thyroid disease (Yes) & -0.347 & 0.205 & -0.424 & 0.115 & -0.193 & 0.491 & -0.270 & 0.330 \\
\hline Hypertension (Yes) & 0.196 & 0.483 & 0.196 & 0.483 & 0.223 & 0.411 & 0.196 & 0.483 \\
\hline
\end{tabular}

Notably, tear size $(\mathrm{mm})$ was the only variable that demonstrated a significant correlation with number of CFUs by cells from SB over the RC tendon. Focusing on bursa over the $\mathrm{RC}$ tendon, tear size was significantly correlated with number of colonies when analyzing $10^{3}$ cells $/$ well (rho $\left.=-0.567 ; p=0.028\right)$ and $10^{4}$ cells $/$ well $($ rho $=-0.645 ; p=0.009$ ). Scatterplot representation of the Spearman's rank correlation coefficient (rho) between tear size and CFU number can be observed in Figure 1.

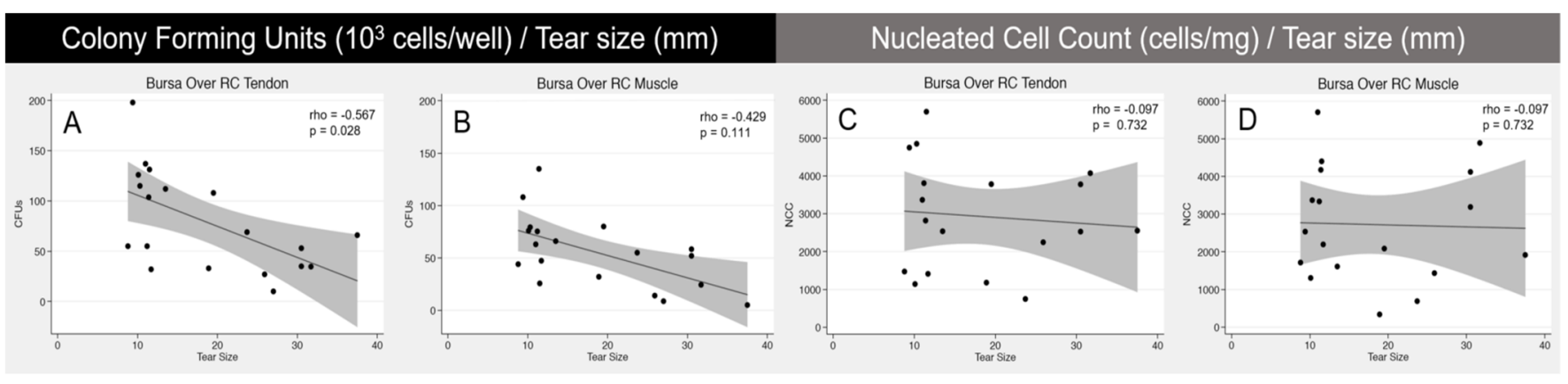

Figure 1. Scatterplot representations of Spearman's rank correlation coefficient analysis. The left scatterplot demonstrates a significant $(p<0.028)$ negative correlation between tear size and number of CFUs from the cells of the SB over the RC tendon (A). The right three scatterplots show no significant correlation between tear size and CFU from SAB over RC muscle (B) or NCC of the cells from SB over RC tendon (C) and muscle (D). Grey shading around regression line represents $95 \%$ confidence interval. 


\subsection{Correlation between NCC and Patient Demographics}

When analyzing the correlation between NCC from SB CTPs over the RC tendon and muscle (Table 2), no statistical correlation was seen with any patient demographics. This analysis included age, sex, height, weight, BMI, tear size, smoking, Brinkman Index, diabetes mellitus, thyroid disease, and hypertension.

Table 2. Spearman's rank correlation coefficient analysis of nucleated cell count (NCC) from the SB over RC tendon and muscle. There was no statistical correlation with all patient demographics and tear characteristics.

\begin{tabular}{ccccc}
\hline & \multicolumn{3}{c}{ Nucleated Cell Count per Milligram } \\
\cline { 2 - 5 } & Bursa Over RC Tendon & Bursa over RC Muscle \\
\cline { 2 - 5 } & rho & $p$-Value & rho & $p$-Value \\
\hline Age & 0.165 & 0.557 & -0.040 & 0.889 \\
Sex (Female) & 0.000 & 1.000 & 0.000 & 1.000 \\
Height (cm) & -0.091 & 0.746 & -0.138 & 0.624 \\
Weight (kg) & -0.363 & 0.184 & -0.038 & 0.894 \\
BMI (kg/m ${ }^{2}$ ) & -0.361 & 0.187 & -0.057 & 0.840 \\
Tear size (mm) & -0.097 & 0.732 & -0.097 & 0.732 \\
Smoking (Non, Former, Current) & -0.445 & 0.096 & -0.078 & 0.782 \\
Brinkman Index (Ciggarettes/d $\times$ y) & -0.299 & 0.280 & 0.028 & 0.922 \\
Diabetes mellitus (Yes) & 0.039 & 0.891 & 0.077 & 0.785 \\
Thyroid disease (Yes) & -0.039 & 0.891 & -0.270 & 0.330 \\
Hypertension (Yes) & -0.229 & 0.411 & -0.295 & 0.2865 \\
\hline
\end{tabular}

\section{Discussion}

The most important finding of this study was that there was no significant correlation between patient demographics and the number of CFUs or NCC of CTPs derived from the $\mathrm{SB}$ over the RC tendon and muscle. Additionally, this study demonstrated a significant negative correlation between increased tear size and the number of CFUs from bursa over RC tendon.

With unsatisfactory retear rates and a long postoperative rehabilitation period [4,38-41], orthopaedic surgeons have begun augmenting RC tears with the readily accessible SB [28-30]. Recent literature has demonstrated that the SB is an abundant source of CTPs that meet the criteria set by the ISCT, including adherence to plastic culture plates, the expression of specific cell surface molecules, and multi-lineage differentiation [17-21]. In vitro studies have further demonstrated the high proliferative potential of these cells [19,24-27]. Although bone-marrow aspirate has long been utilized as a source of CTPs for regenerative orthopaedic surgery $[22,23,42-44]$, studies now show that bursal CTPs have significantly higher proliferation, CFUs, and differentiation ability compared to bone-marrow MSCs [24]. Additionally, Dyrna et al. demonstrated that bursal CTPs showed superior engraftment and survival in tendon tissue than bone-marrow MSCs [27]. These results have led to the development of multiple inexpensive techniques to augment $\mathrm{RC}$ repairs using the SB with minimal manipulation [28-30].

Specific patient demographics and comorbidities have long been associated with RC repair failure, such as advancing age [45,46], smoking [38,47-50], diabetes mellitus [51-54], and obesity $[33,55,56]$, among others [41,57]. When deciding which patients may be good candidates for bursal biological augmentation of RC repairs, these demographics may concern orthopaedic surgeons that their tissue may not be viable. Muench et al. were the first to demonstrate that patient demographics and RC tear characteristics did not alter the proliferation potential of bursal CTPs [36]. The study was limited in that they used NCC, a nonspecific measure of cellular activity that cannot differentiate live, dead, or other mononuclear cells. CTPs are defined partly by their ability to divide to form a clonal population, known as CFUs, which may be a more clinically relevant measure of CTP viability $[13,22]$. The present study demonstrated that the number of CFUs was not 
correlated to patient demographics, further supporting Muench et al.'s conclusion that the SB may be used for biological augmentation regardless of patient demographics [36].

This study is limited as the in vitro nature of CTPs may not mimic the in vivo potential of CTPs in the shoulder. Further studies are needed to understand the relationship between CFUs and the in vivo interaction of CTPs with the healing tendon. Additionally, the study's small sample size $(n=19)$ may result in insufficient statistical power and possible type II error.

Nevertheless, the results of the present study may further ease concerns that certain patient demographics could alter the characteristics of SB CTPs. This tissue complex is easily accessible during RC repair and, for a low cost, may be efficiently used to augment $\mathrm{RC}$ repairs. Future clinical trials are needed to understand the effects of SB CTPs on healing and outcomes of RC repairs.

Author Contributions: D.M. and A.D.M. contributed to conceptualization, experimental design and interpretation of results. D.M., M.B.R.M., N.B. and J.D.J. carried out laboratory experiments and acquired data. D.M., B.C.H., M.T.T., K.V.M., M.R.M., M.R.L. and M.P.C. analyzed the data and ran statistical analysis. D.M. and A.D.M. provided project administration and funding acquisition. All authors contributed to the literature review, drafting, and revising of this manuscript. All authors approved the final version of the manuscript and ensured the accuracy and integrity of the work. All authors have read and agreed to the published version of the manuscript.

Funding: This research received no external funding.

Institutional Review Board Statement: The study was conducted according to the guidelines of the Declaration of Helsinki and approved by the Institutional Review Board of the University of Connecticut Health Center (IRB no. IE-07-224-2).

Informed Consent Statement: Patient consent was waived by Institutional Review Board due to this tissue normally being discarded during arthroscopic rotator cuff repair. No identifying information was linked to the samples.

Data Availability Statement: The data are not publicly available due to concerns over patient privacy. Data available on request.

Conflicts of Interest: D.M., B.C.H., M.R.M., N.B., J.D.J., M.T.T., K.V.M., M.R.M., M.R.L., M.P.C. declare no conflict of interest. A.D.M. is a consultant for and receives research support from Arthrex Inc. (Naples, FL, USA), outside the submitted work. The University of Connecticut Health Center/UConn Musculoskeletal Institute has received direct funding and material support from Arthrex, outside of the submitted work. The company had no influence on study design, data collection, or interpretation of the results or the final manuscript.

\section{References}

1. Oh, L.S.; Wolf, B.R.; Hall, M.P.; Levy, B.A.; Marx, R.G. Indications for rotator cuff repair: A systematic review. Clin. Orthop. Relat. Res. 2007, 455, 52-63. [CrossRef]

2. Day, M.A.; Westermann, R.W.; Bedard, N.A.; Glass, N.A.; Wolf, B.R. Trends Associated with Open Versus Arthroscopic Rotator Cuff Repair. HSS J. 2019, 15, 133-136. [CrossRef]

3. Harryman, D.T., 2nd; Mack, L.A.; Wang, K.Y.; Jackins, S.E.; Richardson, M.L.; Matsen, F.A., 3rd. Repairs of the rotator cuff. Correlation of functional results with integrity of the cuff. J. Bone Jt. Surg. 1991, 73, 982-989. [CrossRef]

4. Galatz, L.M.; Ball, C.M.; Teefey, S.A.; Middleton, W.D.; Yamaguchi, K. The Outcome and Repair Integrity of Completely Arthroscopically Repaired Large and Massive Rotator Cuff Tears. J. Bone Jt. Surg.-Ser. A 2004, 86, 219-224. [CrossRef] [PubMed]

5. Mather, R.C., III; Koenig, L.; Acevedo, D.; Dall, T.M.; Gallo, P.; Romeo, A.; Tongue, J.; Williams, G.J. The Societal and Economic Value of Rotator Cuff Repair. J. Bone Jt. Surg. Am. 2013, 95, 1993. [CrossRef]

6. Gerber, C.; Schneeberger, A.; Perren, S.; Nyffeler, R. Experimental rotator cuff repair. A preliminary study. J. Bone Jt. Surg. Am. 1999, 81, 1281-1290. [CrossRef] [PubMed]

7. Kovacevic, D.; Rodeo, S.A. Biological augmentation of rotator cuff tendon repair. Clin. Orthop. Relat. Res. 2008, 466, 622-633. [CrossRef]

8. Thomopoulos, S.; Genin, G.M.; Galatz, L.M. The development and morphogenesis of the tendon-to-bone insertion-What development can teach us about healing. J. Musculoskelet. Neuronal Interact. 2010, 10, 35-45.

9. Nourissat, G.; Berenbaum, F.; Duprez, D. Tendon injury: From biology to tendon repair. Nat. Rev. Rheumatol. 2015, 11, 223-233. [CrossRef] 
10. Docheva, D.; Müller, S.A.; Majewski, M.; Evans, C.H. Biologics of Tendon Repair. Adv. Drug Deliv. Rev. 2015, 84, 222-239. [CrossRef]

11. Carr, J.B.; Rodeo, S.A. The role of biologic agents in the management of common shoulder pathologies: Current state and future directions. J. Shoulder Elb. Surg. 2019, 28, 2041-2052. [CrossRef]

12. Komura, S.; Satake, T.; Goto, A.; Aoki, H.; Shibata, H.; Ito, K.; Hirakawa, A.; Yamada, Y.; Akiyama, H. Induced pluripotent stem cell-derived tenocyte-like cells promote the regeneration of injured tendons in mice. Sci. Rep. 2020, 10, 3992. [CrossRef] [PubMed]

13. Rodeo, S. Stem Cells 101. Am. J. Sports Med. 2021, 49, 1417-1420. [CrossRef] [PubMed]

14. Beitzel, K.; Allen, D.; Apostolakos, J.; Russell, R.P.; McCarthy, M.B.; Gallo, G.J.; Cote, M.P.; Mazzocca, A.D. US definitions, current use, and FDA stance on use of platelet-rich plasma in sports medicine. J. Knee Surg. 2015, 28, 29-34. [CrossRef]

15. Regulatory Considerations for Human Cells, Tissues, and Cellular and Tissue-Based Products: Minimal Manipulation and Homologous Use Guidance for Industry and Food and Drug Administration Staff Contains Nonbinding Recommendations Regulatory Considerations. In Guidance for Industry and Food and Drug Administration Staff; U.S. Department of Health and Human Services: Washington, DC, USA, 2020. Available online: https:/ /www.fda.gov/regulatory-information/search-fda-guidancedocuments/regulatory-considerations-human-cells-tissues-and-cellular-and-tissue-based-products-minimal (accessed on 8 August 2021).

16. Rodeo, S.A. Moving Toward Responsible Use of Biologics in Sports Medicine. Am. J. Sports Med. 2018, 46, 1797-1799. [CrossRef] [PubMed]

17. Dominici, M.; Blanc, K.L.; Mueller, I.; Slaper-Cortenbach, I.; Marini, F.; Krause, D.; Deans, R.; Keating, A.; Prockop, D.; Horwitz, E. Minimal criteria for defining multipotent mesenchymal stromal cells. The International Society for Cellular Therapy position statement. Cytotherapy 2006, 8, 315-317. [CrossRef]

18. Lhee, S.H.; Jo, Y.H.; Kim, B.Y.; Nam, B.M.; Nemeno, J.G.; Lee, S.; Yang, W.; Lee, J.I. Novel supplier of mesenchymal stem cell: Subacromial bursa. In Transplantation Proceedings; Elsevier: Amsterdam, The Netherlands, 2013; Volume 45, pp. 3118-3121. [CrossRef]

19. Utsunomiya, H.; Uchida, S.; Sekiya, I.; Sakai, A.; Moridera, K.; Nakamura, T. Isolation and characterization of human mesenchymal stem cells derived from shoulder tissues involved in rotator cuff tears. Am. J. Sports Med. 2013, 41, 657-668. [CrossRef]

20. Song, N.; Armstrong, A.; Li, F.; Ouyang, H.; Niyibizi, C. Multipotent mesenchymal stem cells from human subacromial bursa: Potential for cell based tendon tissue engineering. Tissue Eng. Part A 2014, 20, 239-249. [CrossRef] [PubMed]

21. Steinert, A.F.; Kunz, M.; Prager, P.; Göbel, S.; Klein-Hitpass, L.; Ebert, R.; Nöth, U.; Jakob, F.; Gohlke, F. Characterization of bursa subacromialis-derived mesenchymal stem cells. Stem Cell Res. Ther. 2015, 6, 114. [CrossRef]

22. Muschler, G.F.; Midura, R.J. Connective tissue progenitors: Practical concepts for clinical applications. Clin. Orthop. Relat. Res. 2002, 1, 66-80. [CrossRef]

23. Patterson, T.E.; Boehm, C.; Nakamoto, C.; Rozic, R.; Walker, E.; Piuzzi, N.S.; Muschler, G.F. The Efficiency of Bone Marrow Aspiration for the Harvest of Connective Tissue Progenitors from the Human Iliac Crest. J. Bone Jt. Surg.-Am. Vol. 2017, 99, 1673-1682. [CrossRef]

24. Morikawa, D.; Johnson, J.D.; Kia, C.; McCarthy, M.B.R.; Macken, C.; Bellas, N.; Baldino, J.B.; Cote, M.P.; Mazzocca, A.D. Examining the Potency of Subacromial Bursal Cells as a Potential Augmentation for Rotator Cuff Healing: An In Vitro Study. Arthrosc.-J. Arthrosc. Relat. Surg. 2019, 35, 2978-2988. [CrossRef] [PubMed]

25. Morikawa, D.; Muench, L.N.; Baldino, J.B.; Kia, C.; Johnson, J.; Otto, A.; Pauzenberger, L.; Dyrna, F.; McCarthy, M.B.R.; Mazzocca, A.D. Comparison of Preparation Techniques for Isolating Subacromial Bursa-Derived Cells as a Potential Augment for Rotator Cuff Repair. Arthrosc.-J. Arthrosc. Relat. Surg. 2020, 36, 80-85. [CrossRef]

26. Baldino, J.B.; Muench, L.N.; Kia, C.; Johnson, J.; Morikawa, D.; Tamburini, L.; Landry, A.; Gordon-Hackshaw, L.; Bellas, N.; McCarthy, M.B.; et al. Intraoperative and In Vitro Classification of Subacromial Bursal Tissue. Arthrosc.-J. Arthrosc. Relat. Surg. 2020, 36, 2057-2068. [CrossRef]

27. Dyrna, F.; Zakko, P.; Pauzenberger, L.; McCarthy, M.B.; Mazzocca, A.D.; Dyment, N.A. Human Subacromial Bursal Cells Display Superior Engraftment Versus Bone Marrow Stromal Cells in Murine Tendon Repair. Am. J. Sports Med. 2018, 46, 3511-3520. [CrossRef]

28. Muench, L.N.; Kia, C.; Berthold, D.P.; Uyeki, C.; Otto, A.; Cote, M.P.; McCarthy, M.B.; Beitzel, K.; Arciero, R.A.; Mazzocca, A.D. Preliminary Clinical Outcomes Following Biologic Augmentation of Arthroscopic Rotator Cuff Repair Using Subacromial Bursa, Concentrated Bone Marrow Aspirate, and Platelet-Rich Plasma. Arthrosc. Sport. Med. Rehabil. 2020, 2, e803-e813. [CrossRef] [PubMed]

29. Dei Giudici, L.; Castricini, R. Local Autologous Stem Cells Application in Rotator Cuff Repairs: "LASCA" Technique. Arthrosc. Tech. 2020, 9, e1571-e1575. [CrossRef]

30. Freislederer, F.; Dittrich, M.; Scheibel, M. Biological Augmentation With Subacromial Bursa in Arthroscopic Rotator Cuff Repair. Arthrosc. Tech. 2019, 8, e741-e747. [CrossRef] [PubMed]

31. Carballo, C.B.; Lebaschi, A.; Rodeo, S.A. Cell-based approaches for augmentation of tendon repair. Tech. Shoulder Elb. Surg. 2017, 18, e6-e14. [CrossRef]

32. Le, B.T.N.; Wu, X.L.; Lam, P.H.; Murrell, G.A.C. Factors predicting rotator cuff retears: An analysis of 1000 consecutive rotator cuff repairs. Am. J. Sports Med. 2014, 42, 1134-1142. [CrossRef] 
33. Ateschrang, A.; Eggensperger, F.; Ahrend, M.D.; Schröter, S.; Stöckle, U.; Kraus, T.M. Obesity causes poorer clinical results and higher re-tear rates in rotator cuff repair. Arch. Orthop. Trauma Surg. 2018, 138, 835-842. [CrossRef] [PubMed]

34. Yang, L.; Zhang, J.; Ruan, D.; Zhao, K.; Chen, X.; Shen, W. Clinical and Structural Outcomes After Rotator Cuff Repair in Patients With Diabetes: A Meta-analysis. Orthop. J. Sport. Med. 2020, 8, 2325967120948499. [CrossRef] [PubMed]

35. Lobo-Escolar, L.; Ramazzini-Castro, R.; Codina-Grañó, D.; Lobo, E.; Minguell-Monyart, J.; Ardèvol, J. Risk factors for symptomatic retears after arthroscopic repair of full-thickness rotator cuff tears. J. Shoulder Elb. Surg. 2020, 32, 2191-2200. [CrossRef]

36. Muench, L.N.; Baldino, J.B.; Berthold, D.P.; Kia, C.; Lebaschi, A.; Cote, M.P.; McCarthy, M.B.; Mazzocca, A.D. Subacromial Bursa-Derived Cells Demonstrate High Proliferation Potential Regardless of Patient Demographics and Rotator Cuff Tear Characteristics. Arthrosc.-J. Arthrosc. Relat. Surg. 2020, 36, 2794-2802. [CrossRef]

37. Morikawa, D.; LeVasseur, M.R.; Luczak, S.B.; Mancini, M.R.; Bellas, N.; McCarthy, M.B.R.; Cote, M.P.; Berthold, D.P.; Muench, L.N.; Mazzocca, A.D. Decreased Colony-Forming Ability of Subacromial Bursa-Derived Cells During Revision Arthroscopic Rotator Cuff Repair. Arthrosc. Sports Med. Rehabil. 2021, 3, e1047-e1054. [CrossRef]

38. Park, J.H.; Oh, K.S.; Kim, T.M.; Kim, J.; Yoon, J.P.; Kim, J.Y.; Chung, S.W. Effect of Smoking on Healing Failure After Rotator Cuff Repair. Am. J. Sports Med. 2018, 46, 2960-2968. [CrossRef]

39. Garcia, G.H.; Liu, J.N.; Wong, A.; Cordasco, F.; Dines, D.M.; Dines, J.S.; Gulotta, L.V.; Warren, R. Hyperlipidemia increases the risk of retear after arthroscopic rotator cuff repair. J. Shoulder Elb. Surg. 2017, 26, 2086-2090. [CrossRef]

40. Shin, S.J.; Kook, S.H.; Rao, N.; Seo, M.J. Clinical Outcomes of Modified Mason-Allen Single-Row Repair for Bursal-Sided Partial-Thickness Rotator Cuff Tears: Comparison with the Double-Row Suture-Bridge Technique. Am. J. Sports Med. 2015, 43, 1976-1982. [CrossRef]

41. O’Donnell, E.A.; Fu, M.C.; White, A.E.; Taylor, S.A.; Dines, J.S.; Dines, D.M.; Warren, R.F.; Gulotta, L.V. The Effect of Patient Characteristics and Comorbidities on the Rate of Revision Rotator Cuff Repair. Arthrosc.-J. Arthrosc. Relat. Surg. 2020, 36, 2380-2388. [CrossRef]

42. Mazzocca, A.D.; McCarthy, M.B.R.; Chowaniec, D.M.; Cote, M.P.; Arciero, R.A.; Drissi, H. Rapid isolation of human stem cells (connective tissue progenitor cells) from the proximal humerus during arthroscopic rotator cuff surgery. Am. J. Sports Med. 2010, 38, 1438-1447. [CrossRef]

43. Beitzel, K.; McCarthy, M.B.R.; Cote, M.P.; Durant, T.J.S.; Chowaniec, D.M.; Solovyova, O.; Russell, R.P.; Arciero, R.A.; Mazzocca, A.D. Comparison of mesenchymal stem cells (osteoprogenitors) harvested from proximal humerus and distal femur during arthroscopic surgery. Arthrosc.-J. Arthrosc. Relat. Surg. 2013, 29, 301-308. [CrossRef]

44. Voss, A.; McCarthy, M.B.; Singh, H.; Beitzel, K.; DiVenere, J.; Cote, M.P.; Hoberman, A.R.; Nowak, M.; Imhoff, A.B.; Mazzocca, A.D. The Influence of Trocar Fenestration and Volume on Connective Tissue Progenitor Cells (Stem Cells) in Arthroscopic Bone Marrow Aspiration from the Proximal Humerus. Arthrosc.-J. Arthrosc. Relat. Surg. 2017, 33, 1167-1174.e. [CrossRef] [PubMed]

45. McElvany, M.D.; McGoldrick, E.; Gee, A.O.; Neradilek, M.B.; Matsen, F.A. Rotator cuff repair: Published evidence on factors associated with repair integrity and clinical outcome. Am. J. Sports Med. 2015, 43, 491-500. [CrossRef]

46. Saccomanno, M.F.; Sircana, G.; Cazzato, G.; Donati, F.; Randelli, P.; Milano, G. Prognostic factors influencing the outcome of rotator cuff repair: A systematic review. Knee Surg. Sports Traumatol. Arthrosc. 2016, 24, 3809-3819. [CrossRef]

47. Djahangiri, A.; Cozzolino, A.; Zanetti, M.; Helmy, N.; Rufibach, K.; Jost, B.; Gerber, C. Outcome of single-tendon rotator cuff repair in patients aged older than 65 years. J. Shoulder Elb. Surg. 2013, 22, 45-51. [CrossRef]

48. Tashjian, R.Z.; Hollins, A.M.; Kim, H.M.; Teefey, S.A.; Middleton, W.D.; Steger-May, K.; Galatz, L.M.; Yamaguchi, K. Factors affecting healing rates after arthroscopic double-row rotator cuff repair. Am. J. Sports Med. 2010, 38, 2435-2442. [CrossRef]

49. Balyk, R.; Luciak-Corea, C.; Otto, D.; Baysal, D.; Beaupre, L. Do outcomes differ after rotator cuff repair for patients receiving workers' compensation? Clin. Orthop. Relat. Res. 2008, 466, 3025-3033. [CrossRef] [PubMed]

50. Mallon, W.J.; Misamore, G.; Snead, D.S.; Denton, P. The impact of preoperative smoking habits on the results of rotator cuff repair. J. Shoulder Elb. Surg. 2004, 13, 129-132. [CrossRef]

51. Miyatake, K.; Takeda, Y.; Fujii, K.; Suzue, N.; Kawasaki, Y.; Omichi, Y.; Yokoyama, K. Comparable clinical and structural outcomes after arthroscopic rotator cuff repair in diabetic and non-diabetic patients. Knee Surg. Sports Traumatol. Arthrosc. 2018, 26, 3810-3817. [CrossRef]

52. Cho, N.S.; Moon, S.C.; Jeon, J.W.; Rhee, Y.G. The influence of diabetes mellitus on clinical and structural outcomes after arthroscopic rotator cuff repair. Am. J. Sports Med. 2015, 43, 991-997. [CrossRef] [PubMed]

53. Clement, N.D.; Hallett, A.; MacDonald, D.; Howie, C.; McBirnie, J. Does diabetes affect outcome after arthroscopic repair of the rotator cuff? J. Bone Jt. Surg.-Ser. B 2010, 92, 1112-1117. [CrossRef] [PubMed]

54. Chen, A.L.; Shapiro, J.A.; Ahn, A.K.; Zuckerman, J.D.; Cuomo, F. Rotator cuff repair in patients with type I diabetes mellitus. J. Shoulder Elb. Surg. 2003, 12, 416-421. [CrossRef]

55. Kessler, K.E.; Robbins, C.B.; Bedi, A.; Carpenter, J.E.; Gagnier, J.J.; Miller, B.S. Does Increased Body Mass Index Influence Outcomes After Rotator Cuff Repair? Arthrosc.-J. Arthrosc. Relat. Surg. 2018, 34, 754-761. [CrossRef]

56. Warrender, W.J.; Brown, O.L.; Abboud, J.A. Outcomes of arthroscopic rotator cuff repairs in obese patients. J. Shoulder Elb. Surg. 2011, 20, 961-967. [CrossRef] [PubMed]

57. Zhao, J.; Luo, M.; Pan, J.; Liang, G.; Feng, W.; Zeng, L.; Yang, W.; Liu, J. Risk Factors Affecting Rotator Cuff Retear After Arthroscopic Repair: A meta-analysis and systematic review. J. Shoulder Elb. Surg. 2021, in press. [CrossRef] 